AGNIESZKA KAMROWSKA

Instytut Sztuki Mediów

Uniwersytet Pedagogiczny w Krakowie

\title{
Elektroniczny łowca: postać cyborga $w$ kinie science fiction głównego nurtu
}

\begin{abstract}
Kamrowska Agnieszka, Elektroniczny łowca: postać cyborga w kinie science fiction głównego nurtu [Electronic hunter: the cyborg in mainstream science fiction films]. "Images" vol. XXVIII, no. 37. Poznań 2020. Adam Mickiewicz University Press. Pp. 21-34. ISSN 1731-450X. DOI 10.14746/i.2020.37.02.

The aim of this text is to analyze the cyborg motif in mainstream American science fiction films, as represented by the Terminator and RoboCop film series. The cyborg characters presented in these films are focused mainly on violence and destruction, which emphasizes the technophobic attitude of the culture within which these films were made. The only redemption of their otherness is showing their humanity. For a cyborg, its technological provenance is a burden and results in its sense of guilt. In this manner, American science fiction films support anthropocentrism and the conservative status quo.
\end{abstract}

KEYworDs: science fiction, cyborg, mainstream cinema, Terminator film series, RoboCop film series, technophobia

W roku 1960 amerykańscy uczeni Manfred E. Clynes i Nathan S. Kline w pionierskim artykule Cyborgs and space opublikowanym w miesięczniku „Astronautics” zaproponowali termin cyborg na określenie „egzogenicznie rozszerzonego kompleksu organicznego funkcjonującego nieświadomie jako zintegrowany system homeostatyczny. [...] Cyborg programowo zawiera elementy egzogeniczne poszerzające samoregulujące funkcje kontrolne organizmu, aby zaadaptować go do nowych środowisk"[1]. Definicja Clynesa i Kline’a, stworzona w obrębie paradygmatu medycznego, powstała w ramach programu badań kosmicznych i opisywała ludzki organizm sztucznie przystosowany do oddychania pozaziemską atmosferą. Otwiera ona nowe możliwości pojmowania istoty ludzkiej nie jako zamkniętej całości zdeterminowanej do egzystencji w jeden określony sposób, lecz jako materiału wyjściowego do modyfikacji. Potencjalność zmian, jakie stwarza cyborgizacja, daje człowiekowi zupełnie nowe możliwości, nie tyle w dziedzinie kolonizacji nowych światów, lecz w osiąganiu nowych doznań. Badanie możliwości, jakie daje proces cyborgizacji, jest również refleksją nad człowiekiem i jego miejscem w świecie.

Metaforyzacji pojęcia cyborga dokonała Donna Haraway, wpisując ten termin w nurt cyberfeminizmu, a także dostarczając jego nowych interpretacji. Dla Haraway stanowi on metaforę kobiety uwikłanej w role społeczne związane z jej pochodzeniem, pozycją i statusem ma-

[1] M.E. Clynes, N.S. Kline, Cyborgs and space, [w:]

The Cyborg Handbook, red. Ch.H. Gray, New York, London 1995, s. 30-31, tłum. A.K. 
terialnym. Podobnie jak cyborg, kobieta jest Obcym w patriarchalnym porządku, jest istotą podporządkowaną ideologicznemu dyskursowi. „Cyborg powstaje, kiedy problematyczne stają się granice dwojakiego rodzaju: pomiędzy zwierzętami (i innymi organizmami) a ludźmi oraz pomiędzy samokontrolującymi i samorządzącymi maszynami (automatonami) a organizmami, szczególnie ludzkimi (modelami autonomii). Cyborg jest istotą zrodzoną z zetknięcia automatonu i autonomii"[2]. W słynnym Manifeście cyborga [3] Haraway twierdzi, iż dzięki hybrydycznej konstrukcji cyborg jest ważną postacią w kulturze, ponieważ przełamuje dualizmy, między innymi dychotomię gender. Swoim istnieniem podważa istnienie granic pomiędzy człowiekiem a maszyną, dzięki temu mogą zostać zniesione inne bariery społeczne. Klasyczny tekst Haraway pokazał, iż fenomen cyborga jest również fenomenem kulturowym, który może stanowić klucz do opisu rzeczywistości oraz narzędzie do jej zmian. Według Anne Balsamo „ciała cyborgów są transgresywne dla dominującego porządku, nie tylko z powodu swojej «konstrukcyjnej» natury, ale również z powodu niedookreślenia, jakie wiąże się z ich hybrydycznym pochodzeniem" [4].

Amerykańskie kino głównego nurtu długo nie podejmowało prób wykorzystania w swoich produkcjach twórczego potencjału, jaki niosła ze sobą oryginalna wizja cyborga o rozszerzonych możliwościach. Zamiast tego powstały filmy, w których ukazywane są one we właściwy mainstreamowi, nieskomplikowany i odtwórczy sposób. Jak pisze o amerykańskich produkcjach Vivian Sobchack, „filmowe science fiction zawsze jest głęboko zakorzenione w przyziemnej amerykańskiej kulturze, w jej ekonomicznej, technologicznej, politycznej, społecznej i lingwistycznej rzeczywistości, w ideologicznych strukturach, które ukształtowały sposób, w jaki filmy te ukazują czas, przestrzeń i stosunki społeczne" [5]. Konserwatywne status quo, jakie w kinie komercyjnym uosabiają cyborgi, manifestuje się na trzech płaszczyznach wyznaczających główne cechy filmowego cyborga: hybrydyczność, destrukcyjność i cielesność. Te trzy elementy tworzą obraz porządku społecznego jaki te filmy komunikują i w jakim postają. Głównymi cechami tego porządku są technofobia i patriarchat. „Cyborg jest intrygującą metaforą kulturowych i politycznych trosk abstrakcyjnej natury: jego fundamentalna hybrydyczność symbolizuje obalenie tradycyjnych wyobrażeń o porządku, przestrzeni, terytorium i tożsamości, drastycznie podważając sensowność istnienia zarówno indywidualnych, jak i kolektywnych granic"[6].

[2] D.J. Haraway, Primate Visions: Gender, race and nature in the world of modern science, New York 1989, s. 139, tłum. A.K.

[3] Eadem, A Cyborg manifesto: science, technology, and socialist-feminism in the late twentieth century, [w:] eadem, Simians, Cyborgs and Women: The reinvention of nature, New York 1991, s. 149-181.
[4] A. Balsamo, Technologies of the Gendered Body: Reading cyborg women, London, Durham NC 1997, s. 11, tłum. A.K.

[5] V. Sobchack, Screening Space. The American science fiction film, New Brunswick NJ, London 1997, s. 302, tłum. A.K.

[6] D. Cavallaro, Cyberpunk and Cyberculture. Science fiction and the work of William Gibson, London, New Brunswick, NJ, 200o, s. 48, tłum. A.K. 
Cyborgi zaludniające kadry amerykańskich filmów często traktowane są na równi $\mathrm{z}$ androidami i robotami, manifestowana jest ich nienaturalna proweniencja i nadludzkie możliwości. Filmy akcentują ich technologiczne pochodzenie jako istot nieczystych - hybryd ludzkich tkanek i mechanicznych artefaktów. Tym samym wpisują je w porządek Obcego, Innego, komunikując niejednoznaczny stosunek, jaki do technologii żywili zarówno filmowcy, jak i całe społeczeństwo.

Dualne, ambiwalentne konotacje powiązane $\mathrm{z}$ robotami w science fiction jasno ukazują uczucia strachu i pożądania, jakimi ludzie obdarzają technologię. Z jednej strony w postaci robota człowiek projektuje swoje odwieczne pragnienie nieśmiertelności, wcielone w potężny i niezniszczalny sztuczny twór, którego zdolności intelektualne, motoryczne i sensualne znacznie przewyższają możliwości przeciętnej osoby. Z drugiej jednak strony istnieje obawa, iż niezwykle zaawansowana technologia - dla większości ludzi zbyt hermetyczna - może wymknąć się spod kontroli, zagrażając tym samym ludzkości[7].

W analizowanych tu filmach postać cyborga jest figurą w technofobicznym dyskursie: jeżeli występuje tylko jeden, jest on postacią negatywną, jeżeli towarzyszą mu inne, to negatywnym bohaterem jest postać najbardziej zaawansowana technologicznie.

Mainstreamowe filmy hollywoodzkie forsowały wcielenie agresywnego zabójcy. Ta pancerna postać reprezentuje anachroniczną tendencję do stosowania maskulinistycznych metafor technologii. Człowiek ze stali był odpowiednią metaforą dla potężnej i agresywnej maszynerii przemysłowej, lecz nie odpowiada on standardom dzisiejszej zminiaturyzowanej i zinternalizowanej elektroniki. Maskulinistyczna postać cyborga z filmów hollywoodzkich stanowi próbę zbagatelizowania miniaturyzacji technologii i feministycznych zmian w społeczeństwie[8].

Cyborgi wpisują się w obraz konserwatywnego porządku społecznego, przybierając postać muskularnych mężczyzn obdarzonych ogromną siłą fizyczną.

Robocop z filmu Verhoevena i Terminator z obrazów Camerona to prawdopodobnie dwie najlepiej znane i najpopularniejsze realizacje motywu cyborga. Ukazane w tych filmach ciała cyborgów są silne, odporne na zranienia i ból oraz zdolne do natychmiastowej auto-reperacji. Są to również ciała silnie zmaskulinizowane[9].

Nieprzypadkowo w role cyborgów wcielali się aktorzy szczycący się imponującą muskulaturą, ikony body buildingu (a z medycznego punktu widzenia - cyborgi sensu stricto): Arnold Schwarzenegger (Terminator), Dolph Lundgren (Uniwersalny żotnierz), Jean-Claude Van Damme (Cyborg, Uniwersalny żotnierz), Sylvester Stallone (Sędzia Dredd). „Chociaż te ultrabrutalne postaci to tylko jedne $\mathrm{z}$ wielu sposobów przedstawiania

[7] G.C. Buttazzo, Can a machine ever become self-aware?, [w:] Artificial Human, Manic Machines, Controlled Bodies, red. R. Aurich, W. Jacobsen, G. Jatho, Berlin, Los Angeles 2000, s. 45, thum. A.K.
[8] C. Springer, Electronic Eros. Bodies and desire in the postindustrial age, Austin 1996, s. 12-13, tłum. A.K. [9] D. Cavallaro, op.cit., s. 47, tłum. A.K. 
cyborgów we współczesnej kulturze, jest to dominujący model ukazywania cyborga w kinie komercyjnym głównego nurtu" [10].

Prócz samego sposobu przedstawienia również fabularna funkcja cyborga w kinie amerykańskim jest bardzo ograniczona: staje się on swego rodzaju emploi, odgrywa wiecznie tę samą rolę maszyny do zabijania. Nie ma znaczenia, czy cyborg stoi po stronie dobra czy zła, zawsze zabija z taką samą wysoką efektywnością. Wymownym potwierdzeniem tej tezy jest polski tytuł filmu Terminator (1984) Jamesa Camerona - Elektroniczny morderca.

Robocop i Terminator wdarli się do świadomości odbiorców poprzez serie niezwykle popularnych filmów. Ich rysy nadały konkretny kształt koncepcji fuzji ludzkiego organizmu z technologią. Obaj są agresywnymi, brutalnymi cyborgami uosabiającymi fantazje o niepokonanej niszczącej sile. [...] Kino głównego nurtu przedstawia cyborgi jako agresywną i rozbuchaną cielesność. Fizyczność cyborga jest podkreślana, a nie bagatelizowana, ich siła jest czysto fizyczna, nie intelektualna. Najlepiej wychodzi im zabijanie[11].

Podkreślanie destrukcyjnego potencjału cyborgicznych postaci jest elementem, dzięki któremu w kinie komercyjnym technologia nacechowana jest negatywnie, ma wzbudzać nieufność oraz strach.

W taki właśnie sposób ukazany jest jeden z najsłnnniejszych filmowych cyborgów - tytułowy bohater wspomnianego wcześniej Elektronicznego mordercy, Terminator. Pomimo iż do chwili obecnej na srebrnym ekranie pojawiły się kolejne Terminatory: T-10oo (Robert Patrick, Lee Byung-hun), T-X (Kristanna Loken), T-30oo (Jason Clarke), Rev-9 (Gabriel Luna), to właśnie „drewniana” twarz Schwarzeneggera i jego napompowane mięśnie są jednoznacznie kojarzone z postacią Terminatora - ikoną popkultury i najpopularniejszym jak dotąd ekranowym wcieleniem cyborga. Tytułowa rola w filmie Jamesa Camerona stała się znakiem rozpoznawczym aktora, którego przydomek „Terminator" był przez wielu komentatorów wykorzystywany podczas kampanii wyborczej na stanowisko gubernatora stanu Kalifornia w 2003 roku. Jako cyborg Schwarzenegger nie potrzebuje stali, wyposażony w swoją nieludzką muskulaturę on po prostu JEST Terminatorem. W ten sposób emploi aktora dominuje nad każdą rolą, w którą się wciela. „Nieważne, o czym opowiada fabuła - spektakl jego niesamowitego ciała i tak nieodparcie angażuje uwagę widza"[12]. Kamienna, wyprana z emocji twarz wpisana jest w scenariusz i pasuje idealnie do obrazu śmiercionośnej maszyny. Ciało Schwarzeneggera, stanowiące podstawę jego aktorstwa, samo w sobie staje się tekstem, w którym odgrywany bohater - cyborg definiowany jest przez fizyczne, destrukcyjne działanie.

[10] C. Springer, op.cit., s. 95, tłum. A.K.

[11] Ibidem, s. 95-96, tłum. A.K.
[12] L. Mizejewski, Action bodies in futurist spaces: Bodybuilder stardom as special effect, [w:] Alien Zone II. The Spaces of Science Fiction Cinema, red. A. Kuhn, London, New York 1999, s. 155, tłum. A.K. 
Terminator T-8oo, czy też Cyberdyne Systems Model 101 - jak sam siebie nazywa - to cybernetyczny organizm składający się z metalowego endoszkieletu powleczonego żywą, wyhodowaną przez maszyny tkanką. Funkcje mózgu pełni u niego mikroprocesor.

Cyborg jest hybrydą, a więc postacią nieczystą. Może ukazywać swoją siłę, jedynie nakładając zbroję. We wszystkich filmach Terminator pojawia się po raz pierwszy na naszej planecie jako podatna na zranienia, naga istota zgięta w pozycji płodu. Swoją falliczną i stereotypowo męską agresywność nabywa on dzięki wejściu w posiadanie skórzanego ubrania i broni[13].

Sceny pojawienia się każdego z Terminatorów akcentują cielesny wymiar cyborgów. Kamera z lubością kontempluje rozbudowaną muskulaturę Schwarzeneggera, wyraziście zarysowaną rzeźbę mięśni Roberta Patricka czy idealne proporcje Kristanny Loken. Ich ciała są - przywołując cytat z filmu Łowca androidów (Blade Runner, 1982, reż. Ridley Scott) - bardziej niż ludzkie. Jednak, pomimo iż Terminatory z wyglądu tak bardzo przypominają ludzi, ich robotyczna proweniencja szybko zostaje widzowi unaoczniona w bardzo bezpośredni sposób. Przez ponad połowę każdego filmu, kiedy tylko Terminator zostaje „ranny” - z jego ciała wystają chromowane pręty, a metalowa czaszka i inne mechaniczne części ciała widoczne są przez dziury w uszkodzonej powłoce. W pierwszym filmie, kiedy Terminator traci ludzkie oko, w oczodole błyska czerwona, przypominająca laserowy celownik dioda. W części drugiej T-8oo musi naprawić sobie rękę i w tym celu odsłania metalowy szkielet, tnąc mięśnie nożem, zaś w trzecim filmie wyjmuje z ciała zepsutą baterię, która po wyrzuceniu przez okno samochodu eksploduje z siłą małej bomby atomowej.

Pozostałe Terminatory w inny sposób manifestują swoje nieorganiczne pochodzenie. T-1000, T-X i Rev-9 morfują[14] - przekształcają swe wykonane z płynnego metalu ciała w inne postaci ludzkie, wtapiają się w otoczenie czy zmieniają swoje kończyny w śmiercionośną broń. W filmie Terminator 2: Dzień sądu (Terminator 2: Judgment Day, 1991, reż. James Cameron) odgrywający rolę T-10oo Robert Patrick nie prezentuje tak rozbudowanej muskulatury jak Schwarzenegger, a cyborg w jego wykonaniu nie uosabia twardej zmaskulinizowanej technologii, lecz jej wersję sfeminizowaną - „miękką”, zmiennokształtną. Postać T-100o pojawia się również w filmie Terminator Genisys (2015, reż. Alan Taylor) w wykonaniu koreańskiego aktora Lee Byung-huna, którego gładka twarz o niezwykle regularnych, azjatyckich rysach wywołuje efekt obcości.

Agresywny, muskularny wizerunek cyborga dowodzi dominacji fallicznej metafory technologii. Falliczne cyborgi stanowią kontrast do innej, przeciwstawnej metafory współczesnej technologii elektronicznej: „sfeminizowanego" komputera, z jego ukrytymi, pasywnymi i wewnętrznymi

[13] D. Cavallaro, op.cit., s. 47, tłum. A.K.

[14] „Morfizacja (morfing) - efekt pozwalający na całkowicie płynne, nieomal chirurgicznie sterylne przechodzenie od jednej formy postaciowej do innej".

A. Gwóźdź, Technologie widzenia, czyli media w poszukiwaniu autora: Wim Wenders, Kraków 2004, s. 69. 
mechanizmami. Kobiece metafory podkreślają, iż mikro-obwody nie są fizycznie silne czy masywne. Miniaturyzacja, maskowanie i wyciszenie to główne zasady, jakimi rządzi się nowoczesna technologia i jej kobiece metafory[15].

Odtwarzająca w filmie Terminator 3: Bunt maszyn (Terminator 3: Rise of the Machines, 2003, reż. Jonathan Mostow) rolę T-X skandynawska modelka Kristanna Loken stanowi jeszcze bardziej bezpośrednie potwierdzenie tej tezy. Ciało Loken przeczy wizerunkowi fallicznej, zmaskulinizowanej technologii, przenosząc tym samym serię Terminator do czasów współczesnych, kiedy zminiaturyzowana i polimorficzna technologia domaga się zupełnie nowych metafor. Jednakże aktorka Kristanna Loken jest jedynym rewizjonistycznym elementem tej jakże patriarchalnej serii. W części drugiej i trzeciej cyborgi reprezentujące nowoczesną technologię w wersji polimorficznej, a więc sfeminizowanej, ulegają zagładzie w długich scenach miażdżenia, niszczenia i rozczłonkowywania. Zwycięża „stara” technologia w postaci olbrzymiego Arnolda Schwarzeneggera. Nowy porządek, symbolizowany przez nową metaforę technologii, ulega symbolicznej zagładzie i tym samym nie zagraża dominacji starego.

Widać to również w trzech ostatnich filmach z serii „Terminator”: Ocalenie (Terminator: Salvation, 2009, reż. McG), Terminator Genisys i Terminator: Mroczne przeznaczenie (Terminator: Dark Fate, 2019, reż. Tim Miller). Pierwszy tytuł prezentuje szczególnie technofobiczne ujęcie cyborgizacji. Główny bohater Marcus Wright (Sam Worthington) przez połowę filmu uważa (a wraz z nim widzowie), że jest człowiekiem. Marcus to morderca, który ofiarował swoje ciało Cyberdyne Systems, aby uniknąć kary śmierci. Kiedy zostaje ranny w wybuchu miny, naocznie przekonuje się, iż jego wnętrze wypełnia metalowy szkielet, pokryty szybko regenerującą się ludzką tkanką. Przepełniony gniewem postanawia odnaleźć swoich stwórców i zemścić się za odebranie mu człowieczeństwa. Jako cyborg Marcus Wright jest prototypowym modelem infiltratora, którego zadaniem jest wzbudzanie zaufania u ludzi i przekazywanie ich w ręce zabójczych maszyn. Cyborgiczna proweniencja bohatera przepełnia go poczuciem winy, dlatego postanawia ocalić Johna Connora, ofiarowując mu własne serce - symbol człowieczeństwa i jeden z nielicznych ludzkich organów, jakie w nim pozostały. Poświęcając życie, Marcus udowadnia, iż mimo cyborgizacji jest człowiekiem, co potwierdza negatywne nacechowanie technologii w tym filmie, wypełnionym scenami przemocy maszyn wobec bezbronnych ludzi. Kolejna część sagi o Terminatorze nie mogłaby obejść się bez Arnolda Schwarzeneggera. Niestety, obowiązki gubernatora kolidowały ze zdjęciami do filmu, dlatego rolę T-8oo zagrał austriacki kulturysta i aktor Roland Kickinger[16], zaś w miejsce jego twarzy cyfrowo umiesz-

[15] C. Springer, op.cit., s. 104, tłum. A.K.
[16] Do roli T-8oo w tym filmie rozważano również kandydaturę polskiego strongmana Mariusza Pudzianowskiego. 
czono cyfrowo wygenerowane rysy Schwarzeneggera. Dzięki temu walkę z Johnem Connorem w siedzibie Skynetu stacza nagi cyborg, do złudzenia przypominający tytułową postać z Elektronicznego mordercy.

W filmie Terminator Genisys T-8oo powraca jako stary, dobry (uczłowieczony) cyborg o pseudonimie „Tatko”. Ratuje on 9-letnią Sarę Connor przed zabójcami Skynetu i od tej pory wychowuje ją na dzielną wojowniczkę walczącą z maszynami. Ona z kolei uczy go, jak być bardziej ludzkim: żartować, uśmiechać się i podtrzymywać rozmowę. Fabuła Terminator Genisys rozgrywa się w trzech planach czasowych: w roku 1973, 1984 i 2017, co daje możliwość ukazania trzech etapów życia T-8oo. W retrospekcjach z roku 1973 wygląda on jak młody kulturysta znany z pierwszego filmu Jamesa Camerona. W roku 1984 nagi T-8oo ląduje na Ziemi i walczy ze starszym o 11 lat Tatkiem, u którego pojawiają się pierwsze siwe włosy i zmarszczki - wszak jest pokryty ludzką tkanką, która się starzeje. Widać to najlepiej w segmencie z roku 2017, kiedy kompletnie siwy T-8oo ma problemy ze stawami, ale wciąż chce dowieść swojej przydatności i wypełnić rozkaz: ocalić Sarę Connor. Aby tego dokonać, musi walczyć z nowszymi modelami terminatorów: zmiennokształtnym T-10oo, którego przytrzymuje w kwasie do całkowitego rozpuszczenia, oraz polimorficznym T-300o, który przybiera postać Johna Connora (Jason Clarke). Po walce w generatorze pola magnetycznego ranny T-8oo ląduje w zbiorniku z ciekłym stopem metali, z którego wynurza się w finale. Cyborg starszej generacji zawsze zwycięża.

W filmie Terminator: Mroczne przeznaczenie pojawia się najnowszy model cyborga Rev-9 (Gabriel Luna), zbudowany z polimorficznej powłoki i metalowego endoszkieletu, posiadający możliwość rozdzielenia tych dwóch warstw i funkcjonowania jako dwa osobne, niezwykle destrukcyjne byty. Złowieszczego wyglądu nadają tej postaci zwierzęce ruchy, jakie wykonuje podczas szybkiego przemieszczania się. Do walki z Rev-9 z przyszłości zostaje wysłana Grace (Mackenzie Davis) - wysoka, nieco androgyniczna młoda kobieta. Okazuje się jednak, iż na skutek odniesionych ran została ona poddana cyborgizacji, choć sama bohaterka nie uważa siebie za cyborga, bo została zmodyfikowana przez ludzi, a nie maszyny, i nazywa siebie terminem augmented human. Grace jest zdecydowanie najsłabszym ze wszystkich cyborgów w serii Terminator - wymaga podawania lekarstw, często jest osłabiona i nie może chodzić o własnych siłach. Jej starcia z Rev-9 wypełniają prawie cały film, gdyż Grace jest obrończynią młodej Meksykanki Dani Ramos (Natalia Reyes), która jest celem zabójczego cyborga. W walce $\mathrm{z}$ nim wspiera je również znana $\mathrm{z}$ wcześniejszych filmów Sara Connor (Linda Hamilton). Terminator: Mroczne przeznaczenie obfituje w sceny przemocy z udziałem Rev-9, wymierzonej przeciwko trzem kobietom. Osaczone udają się po pomoc do starego dobrego T-8oo (Arnold Schwarzenegger), który przyjął imię Carl, ma przysposobioną rodzinę: żonę i syna, a zawodowo zajmuje się szyciem zasłon. Jego funkcje komunikacyjne również się rozwinęły, Carl jest 
wręcz gadatliwy. Kiedy spotyka Dani i Grace, oczywiście postanawia im pomóc i w akcie poświęcenia ulega destrukcji, doprowadzając do zagłady Rev-9. Starszy, uczłowieczony cyborg (w postaci 72-letniego Arnolda Schwarzeneggera) po raz kolejny pokonuje zły, nowy model. Jedną z najważniejszych cech definiujących filmowego cyborga jest destrukcyjność. W serii Terminator kwestia ta potraktowana została bardzo dosłownie: jedynym celem skonstruowania cyborga jest zabijanie, a dokładniej terminacja - zakończenie działania, czyli pozbawienie życia istot ludzkich. W pierwszej części T-8oo zostaje przysłany z przyszłości, by zabić Sarę Connor, i zabiera się do tego zadania $\mathrm{z}$ typowo mechaniczny sposób - mordując wszystkie Sary Connor, jakie znajdzie w książce telefonicznej. Co prawda w części drugiej T-8oo jest obrońcą Johna Connora - a w części trzeciej także Kate Brewster - lecz w obydwu tych filmach pojawiają się nowsze modele Terminatorów, które przejmują rolę elektronicznych morderców i wykonują ją w ten sam mechaniczny sposób. W Buncie maszyn T-X zabija po kolei wszystkie osoby, które znajdują się na jej liście. Aby wypełnić swoje mordercze zadanie, każdy z Terminatorów jest wyposażony w śmiercionośne artefakty. T-8oo jest pod tym względem mało skomplikowany - najczęściej korzysta z broni palnej lub morduje gołymi rękami, jednak jego następcy to zaawansowane technologicznie maszyny do zabijania. T-10oo jest wykonany z płynnego metalu, dzięki czemu może między innymi przekształcać swoje kończyny w śmiercionośne ostrza różnego rodzaju, zaś ręce T-X wyposażone są niczym szwajcarski scyzoryk, nie brakuje w nich nawet działka plazmowego i miotacza płomieni. T-30oo to nanotechnologiczny model hybrydowy, który zmienia molekularną strukturę wszystkiego, czego dotknie, jest więc najbardziej subtelny, ale i zabójczy w swoich działaniach.

Jednak zabijanie ludzi to tylko jeden $\mathrm{z}$ wymiarów destrukcji, jaka w amerykańskim kinie komercyjnym jest nierozłącznie związana z postaciami cyborgów. Bardziej spektakularne, a przy tym silniej katalizujące aspołeczne potrzeby widzów, są sceny niszczenia dużych fragmentów zabudowań, wybuchów czy pożarów. Według Susan Sontag filmy science fiction lansują estetykę destrukcji, znajdując szczególne upodobanie w sianiu spustoszenia. Wabik filmowej katastrofy polega na zapewnieniu widzom uwolnienia od codziennych obowiązków oraz prezentowaniu silnie moralistycznych historii. Kino fantastycznonaukowe prezentuje beznamiętny, estetyzujący ogląd zniszczenia i przemocy - ogląd technologiczny[17]. W każdej części serii Terminator oglądamy co najmniej jedną długą scenę postępującego zniszczenia: $\mathrm{w}$ pierwszym filmie ofiarą niszczycielskiego cyborga pada posterunek policji wraz ze znajdującą się w nim załogą, w drugiej - siedziba Cyberdyne Systems. Trzecia część, zatytułowana Bunt maszyn, to praw-

[17] Por. S. Sontag, The Imagination of disaster, [w:] eadem, Against Interpretation, New York 1966, s. $213-216$. 
dziwa orgia destrukcji: na początek w gruzy obraca się lecznica dla zwierząt, później złowroga T-X, jadąc wielkim dźwigiem przez pół miasta, niszczy wszystko na swojej drodze, by wreszcie wraz z armią T1 zdemolować główną kwaterę wojska. Terminator: Ocalenie ukazuje postapokaliptyczną Amerykę po Dniu Sądu, pełną ruin, wśród których grasują mordercze maszyny; w oddali widać zgliszcza Los Angeles. Kluczowy dla fabuły ruch oporu pod wodzą Johna Connora prowadzi partyzancką walkę z maszynami, dlatego destrukcja w tym filmie ma charakter operacji paramilitarnych. Terminator Genisys przedstawia apokaliptyczną sekwencję zniszczenia San Francisco jeszcze przed napisami początkowymi, w dalszej części filmu pokazano niszczenie poszczególnych fragmentów miasta i okolic, zaś wysadzoną w finale siedzibę Cyberdyne Systems zagrały budynki informatycznej korporacji Oracle. W Mrocznym przeznaczeniu Rev-9 i Grace najpierw sieją zniszczenie w mieście Meksyk i na pobliskiej autostradzie, potem $\mathrm{w}$ areszcie $\mathrm{w}$ Teksasie i w tamtejszej bazie wojskowej, skąd przenoszą swą destrukcyjną działalność w powietrze, strącając kilka śmigłowców i samolot transportowy.

„Pełne przemocy, brutalne obrazowanie cyborgów wpisuje się we współczesny dyskurs, który współbrzmi z XIX-wiecznym pojmowaniem technologii, różnicy seksualnej i ról gender, aby zbagatelizować transformacje zapoczątkowane przez postmodernistyczny porządek społeczny"[18]. Częścią tego konserwatywnego dyskursu jest tytułowy bohater obrazu RoboCop (1987). Popularność filmu Paula Verohoevena o zrobotyzowanym policjancie Aleksie Murphym zaowocowała serią sequeli i crossoverów, jakie pojawiły się w kinie, na wideo oraz na rynku gier. Podczas pełnienia służby Murphy zostaje brutalnie zmasakrowany przez grupkę bandytów, lecz jego mózg ocalał. Po podłączeniu go do mechanicznego ciała do życia powołany zostaje cyborg superglina tytułowy RoboCop: hybryda ludzkich tkanek i metalowego pancerza „Zaprogramowana tak, by reagować na każde naruszenie prawa i porządku"[19]. Przedstawiona w RoboCopie fuzja ludzkiego organizmu i technologii jest bardzo ograniczona: kiedy lekarzom udaje się ocalić rękę Murphy’ego, specjaliści od cyborgizacji każą ją odciąć, aby w jej miejsce wstawić mechaniczne ramię o nadludzkiej sile. Pomimo tak dużego stopnia mechanizacji bohatera twórcy filmu nie zrezygnowali z podkreślenia zmaskulinizowanej cielesności cyborga - jego mechaniczne ciało przypomina silnie umięśnionego mężczyznę, nawet pancerz na jego piersi został ukształtowany jak prawdziwa muskulatura.

Ciało w RoboCopie jest dosłownie odbudowane technologicznie. Głównym wątkiem jest tutaj pogwałcenie człowieczeństwa przez mechanizację. Choć Murphy jest bardziej ludzki niż maszyna (nie jest jednak jasne, ile z jego ciała poza mózgiem udało się uratować), zostaje to pokazane poprzez ludzkie

[18] C. Springer, op.cit., s. 100, tłum. A.K.

[19] S. Best, Robocop, czyli kryzys subiektywności, tłum. D. Szawarska, „Kwartalnik Filmowy” 2000, nr 31-32, s. 128. 
problemy, jakie trapią Murphy'ego po wtłoczeniu go w skomputeryzowaną egzystencję. Wciąż doświadcza on bólu istnienia, kiedy przypomina sobie swoje poprzednie życie męża i ojca[20].

Wewnętrzne rozterki Murphy’ego idealnie wpisują się w patriarchalny porządek panujący w amerykańskim społeczeństwie. Wzorowy ojciec i mąż nawet po utracie człowieczeństwa wciąż tęskni do społecznych ról, jakie odgrywał w „poprzednim życiu”. Okazuje się jednak, iż role te aplikowane są do jego nowej - zcyborgizowanej egzystencji. W sequelu zostaje wyjaśnione czemu Alex Murphy tak dobrze funkcjonuje jako RoboCop. Otóż wcześniej był on przykładnym mężem, ojcem i katolikiem oraz oddanym swojej pracy gliniarzem. Te cechy - stosowane tradycyjnie do opisu ról społecznych - tutaj stanowią wyznaczniki dobrego funkcjonowania cyborga, a zainstalowane w jego ciele technologiczne artefakty zdają się nie odgrywać żadnej roli. „Robocop jest modelowym przykładem konserwatywnego projektu uratowania rozkładającego się podmiotu burżuazyjnego - ulega dezintegracji wskutek tych samych sił, które konserwatyści tak bardzo cenią - by przywrócić sobie status moralny i prawny jako tradycyjnego podmiotu męskiego: macho, indywidualisty, heteroseksualisty i konserwatysty"[21].

RoboCop podczas wykonywania swoich obowiązków zachowuje się jak niezwykle wydajna maszyna do zabijania. Kiedy w drugim filmie (RoboCop 2, 1990, reż. Irvin Kershner) zainstalowany zostaje program likwidujący morderczy odruch, cyborg psuje się i musi przełamać restrykcje, by móc normalnie funkcjonować. Podobnie jak Terminator, mówi z trudnością, komunikuje się jedynie zaprogramowanymi wcześniej zdaniami, a jego procesy myślowe zostały ukazane jako napisy 'play' czy 'record' w wizjerze. Na początku cyborg nie wie, kim jest i jak się nazywa, a inni ludzie zwracają się do niego, używając wulgarnych wyzwisk. Jest pozbawiony tożsamości czy zdolności do autorefleksji. Jedynym śladem jego poprzedniej osobowości jest trick, jaki wykonuje przy wyciąganiu broni. RoboCop jednak „stopniowo przezwycięża alienację właściwego mu technologicznego funkcjonowania, ponownie syntetyzując rozproszone odłamki pamięci i całkowicie odzyskując swą tożsamość - wstrząsający i groteskowy moment końcowy, kiedy odkrywa wreszcie swoje prawdziwe imię" [22]. Przemiana zachodząca w psychice Murphy'ego-cyborga została ukazana zbyt dosłownie, a nawet absurdalnie: za pomocą śrubokręta zdejmuje on metalowy hełm i spogląda w lustro na swoją upiornie bladą i nieruchomą twarz, naciągniętą na metalową czaszkę za pomocą grubych drutów. Od tej pory w każdym z filmów obnażenie przez bohatera twarzy oznacza doświadczanie przez niego problemów emocjonalnych. Kiedy RoboCop odzyskuje wreszcie „ludzką" tożsamość, musi uciekać. Cyborg obdarzony tożsamością nie daje sobą manipulować, więc nie nadaje się już do wykonywania swoich obowiązków, dlatego Murphy ukrywa 
się w opuszczonej fabryce przed siłami korporacji OCP, która chce go zlikwidować.

Technologia w RoboCopie jest czynnikiem destrukcyjnym: robot ED-209, skonstruowany, aby bronić mieszkańców Detroit, podczas pierwszej prezentacji ryczy jak potwór i zabija kilka przypadkowych osób. Jego następcy, kolejne sporych rozmiarów warczące roboty, również nie spełniają swojej funkcji - nie tylko zabijają, ale i nie dają sobą sterować. Film Verhoevena

[...] wyraża strach całkowicie wyalienowanego zracjonalizowanego, mechanicznego świata, w którym ludzie i części ich ciała są przedmiotem technologicznej obróbki, w którym nie istnieją uczucia, a „ja” jest całkowitą pustką, gdzie nie istnieje tożsamość osobowa, i gdzie symulacja zbliża się do doskonałości. Strach ma więc w RoboCopie charakter dwoisty: jest to po pierwsze strach, że ludzie zostaną zastąpieni przez maszyny (alienacja) i staną się pod względem duchowym i emocjonalnym bezdusznymi racjonalistami, poddanymi symulacji i obróbce technologicznej[23].

W filmie padają słowa „Nikt nie chce być cyborgiem”, które nie pozostawiają wątpliwości co do jego technofobicznego przesłania. Następca RoboCopa stworzony zostaje z mózgu mordercy-narkomana, specjalnie w tym celu odłączonego od aparatury podtrzymującej życie. Nawet ciężko ranny przestępca nie chciał dobrowolnie poddać się cyborgizacji. Z jego tkanek powstaje uzależniony od narkotyków, potężny cyborg, który kieruje się jedynie żądzą zaspokojenia narkotycznego głodu i zabija wszystkich na swojej drodze. Film RoboCop 3 (1993, reż. Fred Drekker) jeszcze głębiej eksploruje motyw technofobicznego nastawienie do cyborgów. Tym razem jest to przedstawione nie na przykładzie Aleksa Murphy’ego, który jest już cyborgiem „uczłowieczonym", lecz za pomocą japońskich cybernetycznych ninja o nazwie Otomo[24]. Z wyglądu są one nieomal nieodróżnialne od ludzi, mają jednak metalowy szkielet, dzięki któremu są odporne na ciosy. Otomo napędzane są energią atomową i kiedy nie mogą pokonać przeciwnika, eksplodują, zamieniając pole walki w małą Hiroszimę. Cybernetyczne ninja symbolizują głęboki lęk Ameryki lat dziewięćdziesiątych przed sterowanymi komputerowo maszynami, na przykład robotami przemysłowymi, przez które wielu pracowników amerykańskiego przemysłu motoryzacyjnego straciło pracę. Pionierami zautomatyzowania linii produkcyjnej byli właśnie Japończycy, i to z powodu ich sukcesów na rynku produkcji samochodów w Stanach Zjednoczonych przemysłowcy postanowili wprowadzić nowe metody i tym samym zredukować zatrudnienie[25].

RoboCop stanowi zdecydowaną krytykę kapitalizmu jako systemu nieludzkiego, bezlitosnego i skorumpowanego, ale krytyka ta jest skierowana

[23] Ibidem, s. 136.

[24] Po japońsku „towarzysz”.

[25] Zob. R. Arnold, Termination or transformation? the relationship between technology, ideology and subjectivity in cinema, „Film Quarterly” 1998, Fall, tłum. A.K. 
także przeciwko technologii. W paranoicznym, technofobicznym świecie RoboCopa technologia znajduje się poza kontrolą. [...] Liczne awarie ED-209 [...] odzyskanie pamięci i uprzedniej tożsamości przez RoboCopa pomimo komputerowego reprogramowania - wszystko to jest świadectwem zawartej w filmie krytyki technologicznej reifikacji, rozumianej jako niezawodna, cybernetyczna kontrola nad światem człowieka, mimo iż jest to świat, który już w jakimś stopniu wypełnia technologia[26].

Trylogia RoboCop powstała na przełomie lat osiemdziesiątych i dziewięćdziesiątych, kiedy nasycenie przestrzeni społecznej technologicznymi wytworami było o wiele mniejsze niż w drugiej dekadzie XXI wieku. Z tego powodu wydawać by się mogło, iż zadaniem zrealizowanego w roku 2014 remake'u RoboCop (2014, reż. José Padilha) będzie nadążyć za tymi zmianami i zaprezentować bardziej przyjazne oblicze technologii, jednak nic bardziej mylnego. Nowy film wypełniony jest technologicznymi gadżetami, przedstawia na przykład upowszechnienie cyfrowej sieci kamer przemysłowych, do której dostęp ma tytułowy bohater, jednak wymowa tego obrazu pokrywa się z konserwatywnym przesłaniem pierwowzoru. Sam proces cyborgizacji budzi w głównym bohaterze, Aleksie Murphym (Joel Kinnaman), podobną odrazę jak w filmowym pierwowzorze $\mathrm{z}$ lat osiemdziesiątych, i choć początkowo domaga się on eutanazji, szybko daje się odwieść od tego pomysłu, aby nie ranić bliskich. Człowieczeństwo RoboCopa ponownie podkreślone jest poprzez silne więzi rodzinne. To miłość do żony i syna pozwala mu przezwyciężyć ograniczenia zamontowane w mózgu i z pozbawionego emocji robota przemienić się w żądnego zemsty gliniarza. RoboCop Murphy jest niezwykle efektywnym policjantem, dokonuje wielu zatrzymań, nie jest nawet przesadnie brutalny. O jego destrukcyjnym potencjalne przypominają jednak dwie długie sekwencje strzelanin. Przedstawione z punktu widzenia cyborga, przypominają gry wideo, w prawym górnym roku wizjera/ekranu widać licznik pokazujący, ilu przeciwników pozostało do unicestwienia, zaś szybkie ruchy cyborga i jego ogromna skuteczność przypominają, że mamy do czynienia z maszyną do zabijania. Technologiczny pancerz ma siać postrach nadludzkim wyglądem: zbyt wysokim wzrostem i zbyt szerokimi ramionami oraz czarną barwą, na jaką zamieniono początkowy srebrny kolor powłoki. Sam RoboCop jest jednak bardzo ludzki: posługuje się bronią palną, którą wyciąga niczym kowboj z kabury na biodrze, jeździ na motocyklu, może zostać śmiertelnie ranny. Te elementy sprawiają, że cyborg Alex Murphy, pomimo całego technologicznego sztafażu, jest po prostu kolejnym filmowym gliną z ładną żoną i miłym synkiem, zaś jego robotyczna proweniencja to spisek chciwej korporacji. Również Kongres nie daje się omamić machinacjom technologicznego lobby i utrzymuje prawo zakazujące robotów na amerykańskich ulicach. Konserwatywne, technofobiczne status quo po raz kolejny zwycięża.

[26] S. Best, op.cit., s. 131. 
Cyborg to istota z pogranicza dwóch światów: natury i techniki, i ta dwoistość jest wpisana w jego egzystencję. Owa schizofreniczna sytuacja jest udziałem filmowego cyborga, który najczęściej nie chce nim być i pragnie śmierci albo chce uchodzić za człowieka. Jako bohater pozytywny powołuje się na swoje człowieczeństwo, jako negatywny jest wcieleniem zabójczej techniki. W mainstreamowych reprezentacjach postaci cyborga liczą się w istocie tylko dwie umiejętności: zachowania człowieczeństwa i walki wręcz, bo to do niej tak naprawdę sprowadza się większość starć. Cyborg ma być przede wszystkim człowiekiem, rozszerzone możliwości związane są głównie z przemocą. W ten sposób triumfuje antropocentryzm, a nowy potencjał cyborga zredukowany został do funkcji destrukcyjnej, wpisując się w szeroki dyskurs amerykańskiej technofobii. „Badając ideologiczne, psychologiczne i fizjologiczne atrybuty cyborgów, należy wziąć pod uwagę następujące kwestie: (1) cyborg jest zarówno stworzeniem mitycznym, jak i tworem realiów społecznych; (2) cyborg uosabia sprzeczne wizje siły i bezsilności; (3) cyborg personifikuje kulturowe lęki i obawy" [27]. Podczas analizy motywu cyborga w obu filmowych seriach reprezentujących kino głównego nurtu na pierwszy plan wysuwa się wątek złowrogiej technologii, która powołała go do życia. Przybiera ona postać morderczych maszyn lub technokratycznej, żądnej zysków korporacji, a postać cyborga staje się figurą w technofobicznym wywodzie. „Znaczenie technologii daleko wykracza poza kwestię zwykłej mechaniki, zazwyczaj jest ona kluczową figurą ideologicznego dyskursu"[28]. Dla wielu Amerykanów technologia stanowi źródło nieuświadomionego lęku, ponieważ niesie ze sobą potencjał zmian, które mogłyby położyć kres tradycyjnemu porządkowi i jego instytucjom. Jedną z nich jest amerykańskie kino głównego nurtu, dlatego też w jego interesie jest dyskredytowanie obrazu nowoczesnej technologii, co czyni w sposób nie tylko świadomy, ale i spektakularny. Z drugiej strony cyborgi, takie jak Terminator czy RoboCop, stanowią ostatni jak dotąd etap w ewolucji rdzennie amerykańskiego mitu łowcy. Ewolucja ta przebiega od archetypicznego indiańskiego myśliwego, przez zdobywcę pogranicza, aż po reprezentującego erę ponowoczesną łowcę technologicznego - cyborga.

Film hollywoodzki zajmuje w kwestii mitu łowcy sprzeczne stanowisko. $\mathrm{Z}$ jednej strony medium to samo w sobie stanowi apoteozę technologicznego postępu, podbijając serca publiczności efektami specjalnymi, które ciągle ewoluują, aby zapobiec nudzie. Kino produkuje utopijne opowieści o triumfach technologii przeznaczone dla wielkiego ekranu, który kocha prędkość i wielki format, tajemnicę nieistniejącego, ale nie niewyobrażonego. Z drugiej strony filmy od dawna pielęgnowały dystopijne wizje maszyn jako złośliwej plagi, złowrogiej siły, która rozprzestrzenia się i zagraża ludzkości pozbawieniem jej duszy. W ten sposób film krytykuje świat, którego sam jest częścią[29].

[27] D. Cavallaro, op.cit., s. 45-46, tłum. A.K. [28] M. Ryan, D. Kellner, Technophobia, [w:] Alien Zone..., s. 58, tłum. A.K.
[29] J. Hocker Rushing, T.S. Frentz, Projecting the Shadow. The cyborg hero in American film, Chicago, London 1995, s. 47, tłum. A.K. 
Arnold R., Termination or transformation? - the relationship between technology, ideology and subjectivity in cinema, ,Film Quarterly” 1998, Fall

Aurich R., Jacobsen W., Jatho G. (red.), Artificial Human, Manic Machines, Controlled Bodies, Berlin, Los Angeles 2000

Balsamo A., Technologies of the Gendered Body: Reading cyborg women, London, Durham 1997

Best S., Robocop, czyli kryzys subiektywności, tłum. D. Szawarska, „Kwartalnik Filmowy" 2000, nr 31-32

Cavallaro D., Cyberpunk and Cyberculture. Science fiction and the work of William Gibson, London, New Brunswick 2000

Gray Ch.H. (red.), The Cyborg Handbook, New York, London 1995

Gwóźdź A., Technologie widzenia, czyli media w poszukiwaniu autora: Wim Wenders, Kraków 2004

Haraway D.J., Primate Visions: Gender, race and nature in the world of modern science, New York 1989

Haraway D.J., Simians, Cyborgs and Women: The reinvention of nature, New York 1991

Hocker Rushing J., Frentz T.S., Projecting the Shadow. The cyborg hero in American film, Chicago, London 1995

Kuhn A. (red.), Alien Zone. Cultural theory and contemporary science fiction cinema, London, New York 1999

Kuhn A. (red.), Alien Zone II. The spaces of science fiction cinema, London, New York 1999

Sobchack V., Screening Space. The American science fiction film, New Brunswick, NJ, London 1997

Sontag S., Against Interpretation, New York 1966

Springer C., Electronic Eros. Bodies and desire in the postindustrial age, Austin 1996 